Int. J. Dev. Biol. 54: 1565-1574 (2010)

doi: $10.1387 / \mathrm{ijdb} .103206 \mathrm{kl}$

\title{
DNA methylation reprogramming and DNA repair in the mouse zygote
}

\author{
KONSTANTIN LEPIKHOV*, MARK WOSSIDLO, JULIA ARAND and JÖRN WALTER \\ University of Saarland, Institute for Genetics/Epigenetics, Saarbrücken, Germany
}

\begin{abstract}
Here, we summarize current knowledge about epigenetic reprogramming during mammalian preimplantation development, as well as the potential mechanisms driving these processes. We will particularly focus on changes taking place in the zygote, where the paternally derived DNA and chromatin undergo the most striking alterations, such as replacement of protamines by histones, histone modifications and active DNA demethylation. The putative mechanisms of active paternal DNA demethylation have been studied for over a decade, accumulating a lot of circumstantial evidence for enzymatic activities provided by the oocyte, protection of the maternal genome against such activities and possible involvement of DNA repair. We will discuss the various facets of dynamic epigenetic changes related to DNA methylation with an emphasis on the putative involvement of DNA repair in DNA demethylation.
\end{abstract}

KEY WORDS: DNA repair, zygote, DNA demethylation, epigenetic reprogramming

\section{Introduction}

The cellular identity is defined by the composition of RNAs, proteins and other macromolecules. The blueprint of this information resides in the genome, which uses in various cell types and at various developmental stages different parts of its information content for gene expression. This differential gene expression is highly regulated and has its central basis in the differential organization of chromatin along the invariant genomes, established in so called epigenome. The epigenome, which is specific for different cell types, is controlled by a complex interplay between histone and DNA modifications (Jenuwein and Allis, 2001; Kouzarides, 2007). The unique distribution of differentially modified nucleosomes along genomic DNA, which itself is also specifically modified by methylation and hydroxymethylation at cytosine residues, allows the existence of virtually unlimited possible variations of a particular genome. Thank to such variability, cells containing the same DNA sequence can belong to thousands of different cell types comprising different tissues in complex multicellular organisms. The process, by which heritable phenotype is achieved through modification of a chromosome, that involves no alteration to the underlying DNA sequence, is defined as epigenetics (Berger et al., 2009). The first level of epigenetic information is encoded in the distribution profile of 5methylcytosine $(5 \mathrm{mC})$ residues which in animals are almost exclusively found within CpG dinucleotides and impose gene silencing (Bird and Wolffe, 1999). Another level includes various histone modifications, such as methylation, acetylation, phosphorylation, ubiquitination, sumolyation and ADP-ribosylation, as well as numerous variants of core and linker histones (Kouzarides, 2007). Since different cell types have different epigenomes, during development the epigenome of the progenitor cell changes or is programmed/reprogrammed upon differentiation into specialized tissue specific cell type.

The mammalian development begins with the fusion of two epigenetically distant cells: an egg and sperm. The resulting zygote within few hours reshapes both epigenomes and developes further to totipotent preimplantation embryo, which later gives rise to pluripotent cells, residing in the inner cell mass of a blastocyst (Evans and Kaufman, 1981; Sherman, 1975). The contact of a spermatozoa and an oocyte is the first trigger, which turns on the developmental program stored in the mature oocyte apart from the maternal DNA. Once being set off, the program can also act on genomes, which might have various origins and specifications, by converting their epigenetic features into embryo specific state, or in other words - reprogramming them. This ability allows different manipulations with the zygote such as the creation of parthenogenetic (monoparental) embryos, and nuclear/pronuclear

Abbreviations used in this paper: $5 \mathrm{mC}$, 5-methylcytosine EGA, embryonic gene activation; PGC, primordial germ cell.

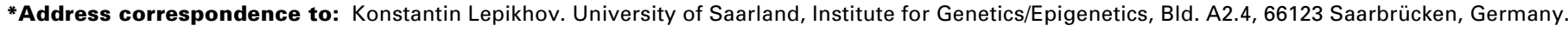
Fax: +49-681-3022703. e-mail: k.lepikhov@mx.uni-saarland.de
} 
transfer, including interspecies transfer (Chang et al., 2003; Hammer et al., 2001; Liu et al., 2004b; McGrath and Solter, 1983; McGrath and Solter, 1984; McGrath and Solter, 1986). The mature oocyte, awaiting the fertilization at metaphase II, gets activated by the penetrating sperm, but it also can be artificially activated in vitro by chemicals, or even by temperature and $\mathrm{pH}$ shifts (Meo et al., 2004; Nagai, 1987; Prather et al., 1991). After activation or fertilization, the oocyte completes meiosis II and one set of maternal chromosomes is extruded as second polar body. The remaining haploid set decondenses and forms a separate maternal pronucleus. Also the sperm DNA penetrated into the oocyte decondenses, exchanging DNA bound protamines against histones derived from the oocyte and gets packaged into a separate pronucleus, that contains expanding interphase like chromatin. The structural reorganizations of the parental genome lead to functional changes from transcriptionally inactive state to transcriptionally active. Some transcriptional activity is detected already in the developing zygote and the total embryonic gene activation (EGA) occurs at 2-cell stage in mouse, or at 8-16 cell stage in bovine and rabbit embryos (Kanka, 2003).

\section{DNA methylation reprogramming}

The very first studies of genome wide DNA methylation by Hpall methylation sensitive digestion in mammalian gametes and preimplantation embryos revealed that sperm DNA is hypermethylated, while DNA from the oocyte is relatively undermethylated (Monk etal., 1987). Further studies using bisulfite sequencing could verify this for selected single copy genes and repetitive elements (Oswald et al., 2000). Nevertheless there were also repetitive elements found, which are highly methylated in both gametes, like IAP and Etn (Kim et al., 2004; Lane et al., 2003). The rapidly developing genome wide high-throughput DNA methylation analysis technologies provide insight into sperm DNA methylation profile. These data show, that, indeed, repetitive elements, intronic and intergenic sequences are highly methylated (Popp et al., 2010), but promoter methylation patterns resemble these of ES cells, excluding promoters of pluripotency related genes (Farthing et al., 2008). Further development of methods for comprehensive DNA methylation data analysis will soon enable the follow up research on oocytes and cleavage stage embryos.

After fertilization the overall methylation level goes down, reaching its minimum at early morula stage (Kafri et al., 1993; Santos et al., 2002). First de novo methylation event coincides with the differentiation of cells in the developing blastocysts into inner cell mass (ICN) and trophectoderm. DNA methylation is clearly detectable by $5 \mathrm{mC}$ specific antibodies in ICN, which gives rise to the embryo proper, but to lesser extent in the trophectoderm, which forms placenta after the implantation into uterus (Dean et al., 2001). The most remarkable event is the loss of $5 \mathrm{mC}$ specific antibody signal, observed in the paternal pronucleus of zygote prior the first round of replication, which was interpreted as active paternal DNA demethylation (Mayer et al., 2000; Oswald et al., 2000; Rougier et al., 1998; Santos et al., 2002). The suggested reduction of DNA methylation in the paternal pronucleus was also confirmed by bisulfite sequencing (Oswald et al., 2000; Wossidlo et al., 2010). The thorough investigations revealed that paternal demethylation starts after the replacement of protamines by histones, proceeds up to the beginning of DNA replication (Lepikhov and Walter, 2004; Santos et al., 2002) and probably continues further (Wossidlo et al., 2010). According to $5 \mathrm{mC}$ antibody signal, the demethylation process affects most of $5 \mathrm{mC}$ content in the paternal pronucleus of the mouse zygote, while maternal DNA retains steady level of methylation. The loss of $5 \mathrm{mC}$ antibody signal is accomplished as early as 6-8 hours after fertilization (Santos et al., 2002). At the same time bisulfite analyses of Line1 and Etn repetitive sequences reveal rather modest reduction in methylation (Wossidlo et al., 2010).

Since both methods utilize different principles, each has its flaws and advantages. The genomic regions chosen for bisulfite analysis might not be representative for showing global changes in DNA methylation and the PCR followed after bisulfite treatment could be biased towards amplification of either methylated or nonmethylated sequences. At the same time the antibody binding could be affected by the distribution pattern of the epitope, thus not reflecting the actual amount of the methylation (Weber et al., 2005). The possibility of further modification of $5 \mathrm{mC}$ to 5 hydroxymethylcytosine $(5 \mathrm{hmC})$ should also be considered because, in this case, $5 \mathrm{mC}$ is no more detectable by specific antibody, but still indistinguishable from $5 \mathrm{hmC}$ by bisulfite analysis (Jin etal., 2010). The potential sources of zygotic demethylation data variability and its dependence on the methods used are discussed elsewhere (Aranyi and Paldi, 2006).

Though sometimes being variable in the degree of progression, the zygotic paternal demethylation seems to be common among mammals and is so far reported for mouse (Oswald et al., 2000; Rougier et al., 1998), rat (Dean et al., 2001; Zaitseva et al., 2007), human (Fulka et al., 2004), pig (Dean et al., 2001; Fulka et al., 2006), cattle (Dean et al., 2001), sheep (Hou et al., 2008) and rabbit (Lepikhov etal., 2008). Mouse zygotes serve as typical and relatively well characterized model to study epigenetic reprogramming in mammalian preimplantation embryos, therefore most of research data described and discussed here relate to the experiments on mouse embryos and gametes.

It is important to mention, that differentially methylated regions (DMRs) of imprinted genes and certain classes of repeat sequences remain refractory to the general demethylation (Lane et al., 2003; Oswald et al., 2000). In fact both paternal and maternal imprints escape further demethylation during embryonic cleavage stages, where so-called "passive, i.e. replication dependent, DNA demethylation takes place. One of the intriguing questions concerning the demethylation in zygotes is the selectivity of the process. What protects the maternal DNA and paternal imprints against demethylation, or alternatively - what targets the demethylation machinery to the sequences being demethylated? Another alternative, which should also be considered is the selective re-methylation occurring immediately after non-selective global demethylation. The instructive role can be assigned to chromatin structure, to specific DNA binding factors or both.

\section{Chromatin modifications in the zygote}

Besides DNA methylation changes, the chromatin structure of gametes is also altered upon their fusion. The chromatin of sperm is dramatically different from that of oocyte. Unlike histone containing oocyte chromosomes, sperm DNA is packaged by protamines. Only a minor portion of sperm chromatin ( $1 \%$ in mouse and 
up to $10 \%$ in human) has a histone containing nucleosome like structure. ChIP-on-chip analysis of histones in sperm chromatin revealed, that nucleosomal structures are maintained at promoter region of developmentally important genes (Brykczynska et al., 2010; Hammoud et al., 2009). After fertilization, the tight protamine packaging of sperm genome is quickly replaced by histone nucleosomes packaging. These maternally provided histones assemble into nucleosomes that lack histone methylation marks but are heavily pre-acetylated (Adenot et al., 1997; Santos et al., 2002). In contrast, the maternal chromatin in mature oocyte is hypoacetylated and contains various types of histone methylation marks (Arney et al., 2002; Kim et al., 2003; Santos et al., 2005). In the first hours post fertilization the paternal pronucleus acquires mono-methylation marks, such as H3K4me1, H3K9me1 and H3K27me1 (Lepikhov and Walter, 2004; Santos et al., 2005). During further development repressive and transcription-activating modifications behave differently - activating H3K4 methylation progresses up to tri-methylated form in late zygotes (Lepikhov and Walter, 2004; van der Heijden et al., 2005), while the stable repressive methylation marks H3K9me2-3, H3K27me3 and H4K20me3 are mostly absent from paternal pronuclei through all zygotic stages. However, these histone methylation marks are detectable in the maternal chromatin through all the zygotic stages. Furthermore, the asymmetry between the two paternal pronuclei is also reflected by preferential accumulation of $\mathrm{H} 3.3$ histone variant in paternal pronuclei in PN2 - PN3 stage zygotes (Torres-Padilla et al., 2006; van der Heijden et al., 2005). The dynamics of histone modifications in relation to DNA methylation changes are schematically pictured on Fig. 1.

\section{Links between DNA and histone modification reprogramming}

The maternal nucleosomes are marked by repressive histone marks and retain the methylation status of DNA (Fuks et al., 2003). Therefore it is tempting to assume, that the repressive chromatin structure prevents maternal DNA from being demethylated. Indeed, there are some indirect evidences supporting this assumption. Liu et al. have demonstrated the ability of germinal vesicle (GV) oocytes to re-methylate the implanted demethylated paternal pronuclei and this re-methylation was also accompanied by H3K9 methylation (Liu et al., 2004a). However, at the same time the artificial induction of $\mathrm{H} 3 \mathrm{~K} 9 \mathrm{me} 2$ in paternal pronuclei by treating the zygotes with protein synthesis inhibitor cycloheximide did not abolish DNA demethylation (Liu et al., 2004a). These data provide evidences, that DNA demethylating activity is inactive in GV oocyte and is triggered by the fertilization and completion of the meiosis. Similarly, the role of differential histone acetylation was also suggested (Cervoni and Szyf, 2001). Spinaci et al. reported the induced demethylation of maternal DNA in mouse zygotes, which were derived from oocytes with artificially in- creased histone acetylation levels (Spinaci et al., 2003). The induced maternal demethylation also required the presence of DNA methyltransferase inhibitor 5-Aza-cytidine. Unfortunately this work has not been followed up and we could not reliably reproduce these data. Overall the data do not show a clear pattern of interdependence between DNA methylation and the regulatory role of certain histone modification on DNA methylation reprogramming. The histone - DNA methylation hierarchy is still questionable because examples for both as the higher-ranked player exist.

The leading role of histone modifications was shown in the following examples: in Neurospora crassathe presence H3K9me3

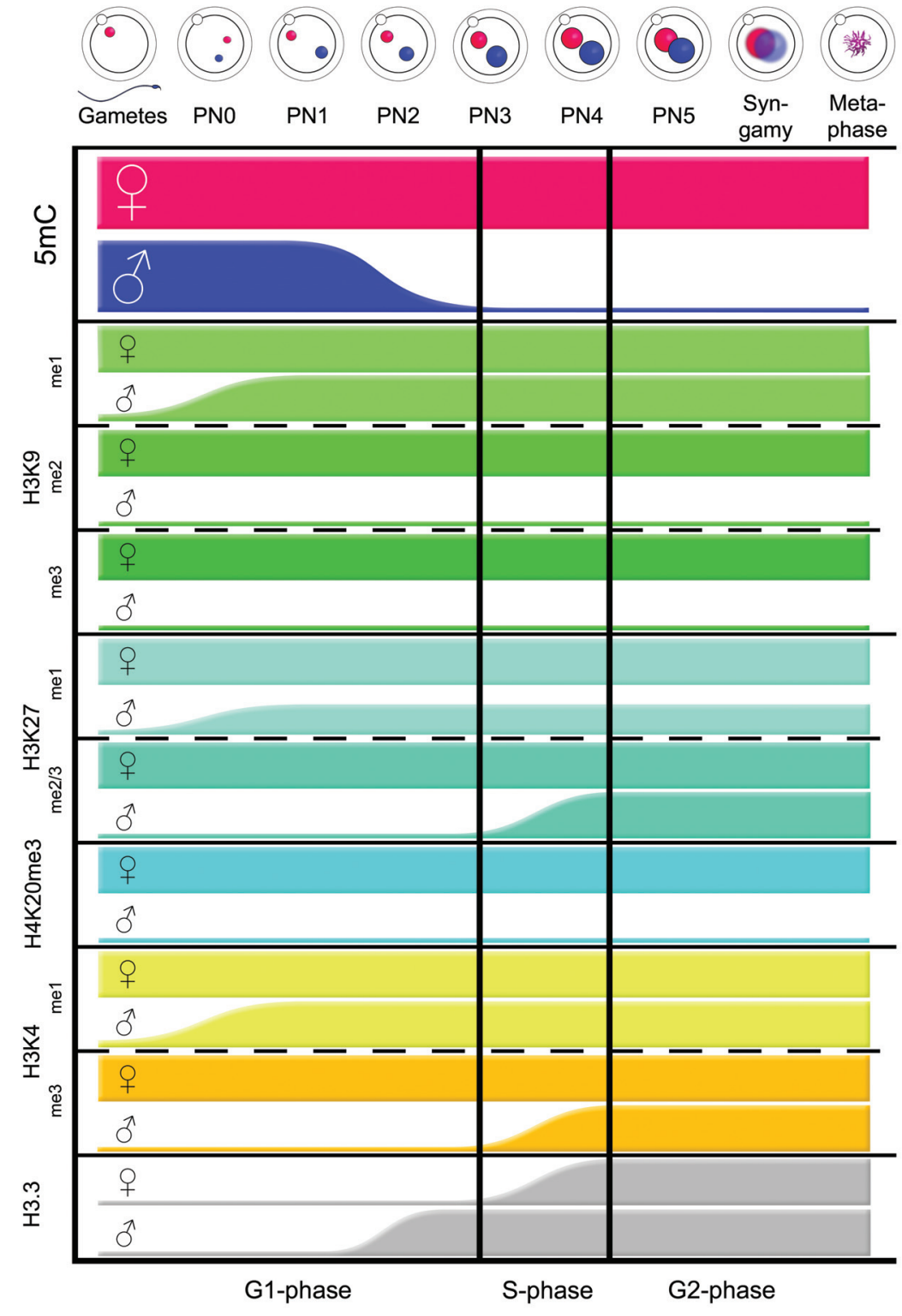

Fig.1. Dynamics of DNA methylation, histone exchange and histone modifications in the zygote. The thickness of the bars reflects the relative amount of particular epigenetic mark in separate parental pronuclei. The data presented summarized from the following references: Arney et al., 2002; Erhardt et al., 2003; Lepikhov and Walter, 2004; Santos et al., 2002; Santos et al., 2005; Sarmento et al., 2004; Torres-Padilla et al., 2006; van der Heijden et al., 2005. 
but not H3K9me2 is required for establishing DNA methylation (Tamaru et al., 2003). In in vitro experiments the complex of Dnmt3a/Dnmt3L methyltransferases preferentially binds to histone $\mathrm{H} 3$ methylated at lysine 9 but not at lysine 4 thus indicating the guiding role of histone modifications in setting up DNA methylation by de novo Dnmt3a methyltransferases (Zhang et al., $2010 \mathrm{~b})$. The physical and functional interaction between histone methyltransferases Suvar39h, which establishes repressive histone methylation marks, and DNA methyltransferases Dnmt3b further corroborates the superiority of chromatin modifications over DNA methylation (Lehnertz et al., 2003). Similarly G9a and Ezh2 histone methyltransferases were also shown to direct DNA methylation in ES cells. (Epsztejn-Litman et al., 2008; Vire et al., 2006).

On the other hand, the regulation of histone modifications patterns by DNA methylation was also demonstrated. The depletion of DNA methylation by 5-Aza-cytidine treatment negatively influences H3K9me3 and H3K27me3 (Komashko and Farnham, 2010). The specially engineered transgene with regulated methylation status also associates with H3K9 methylation and looses histone acetylation if forced to be methylated (Hashimshony et al., 2003).

In general these examples show that in many cases histone modifications and DNA methylation are closely related to each other. Therefore the proper or permissive chromatin environment might be one of the conditions required for selective DNA methylation reprogramming in mammalian zygote. Indeed, sperm DNA undergoes demethylation only after histone-protamine exchange and obviously not during the transition period, when DNA could be free from packaging proteins and hence accessible for demethylation enzymes (Lepikhov and Walter, 2004). In agreement with this suggestion is the fact, that in somatic cell nuclear transfer derived (SCNT) embryos the donor DNA is also subjected to demethylation though the protamine - histone exchange step is missing in this case (Lepikhov et al., 2008; Wossidlo et al., 2010).

\section{Non-chromatin factors influencing DNA demethylation}

The chromatin environment seems not to be the only essential prerequisite for zygotic demethylation. A couple of publications show that other DNA binding proteins are also involved in the regulation of the process. The depletion of maternally provided DNA/RNA binding factor PGC7/Stella from maternal pronucleus induces demethylation of maternal DNA alongside with paternal (Nakamura et al., 2007). This factor, ubiquitously provided by oocyte, serves as protector against the demethylating activity in zygote though it is shown to be equally distributed among both parental pronuclei. Why the protection by PGC7/Stella is only effective in the maternal pronucleus - is still an open and very intriguing question. Methyl-CpG binding protein 3 (MBD3) has also been shown to provide the protection against demethylation. But its function is restricted to secure the paternal imprints maintenance such as methylation of differentially methylated domain (DMD) of H19 gene (Reese et al., 2007). The role of MBD3 in the imprints protection is also associated with repressive chromatin remodeling complexes such as NuRD since MBD3 is part of the complex and its depletion negatively influences the complex formation (Ho and Crabtree, 2010; Reese et al., 2007).
Recent reports have also shown the implication of Elp3, a component of the elongator complex, into the paternal demethylation in zygotes. The knockdown of the protein resulted in impaired demethylation (Okada et al., 2010). It is not yet clear if the protein is directly involved in demethylation, but it possesses so-called "radical SAM" domain which is known to be present in the enzymes, catalyzing radical reactions and using Sadenosylmethionine (SAM) as co-factor (Wang and Frey, 2007). The overexpression of Elp3, mutated within radical SAM domain, in mouse zygotes had similar effect as Elp3 knockdown - the paternal DNA demethylation was abolished (Okada et al., 2010) suggesting the enzymatic involvement of Elp3 in the demethylation process.

\section{DNA demethylation in primordial germ cells and the involvement of DNA methyltransferases in methylation reprogramming}

Comparably to the preimplantation development also the primordial germ cell (PGC) development includes a demethylation process, which occurs in postimplantation mouse embryos between $10.5 \mathrm{dpc}$ and $12.5 \mathrm{dpc}$. This demethylation is believed to be active because Dnmt1 was shown to be present in the nuclei and the process is very fast (Hajkova et al., 2002; Seki et al., 2005).

This demethylation process in PGCs has some similarities and differences to the process in the zygote and preimplantation embryos: in both cases the global reduction of methylation, i.e. detectable by immunofluorescence, is achieved. But in PGCs the imprints and IAP elements also undergo a rapid demethylation process (Hajkova et al., 2002; Lee et al., 2002). It is not clear if demethylation in PGCs and zygotes follow the same pathways and involve the same mechanisms. If the mechanisms are similar, then the differences in demethylated target sequences could be explained by a differential protection, targeting or re-methylation. The immunocytochemistry analyses show that the histone modification patterns share similar features, such as enrichment in H3K4 methylation, depletion of repressive H3K9me2, H3K9me3 and H3K27me3 (Hajkova et al., 2008; Seki et al., 2005). At the same time the composition and localization of DNA methyltransferases in PGCs differs from that in zygotes. Whereas in PGCs Dnmt3a is absent and Dnmt3b is located in the cytoplasm (Hajkova et al., 2002), in zygotes Dnmt3a is present from one cell stage to 8 cell stage and Dnmt3b can be observed from two cell stage on in the nuclei (Hirasawa et al., 2008). It could be assumed that Dnmt3a and Dnmt3b are responsible for maintaining methylation at specific sequences, but bisulfite sequencing of Dnmt3a/ $3 \mathrm{~b}$ deficient blastocysts has shown that both enzymes are not essential for the imprint maintenance, at least for the H19 and Dlk/ Gtl2 DMR, but Dnmt1s (somatic isoform) is required for the maintenance of DMRs methylation (Hirasawa et al., 2008). That was quite surprising because Dnmt1o (oocyte-specific isoform) was reported to be absent from the nuclei in the preimplantation development except for 8 cell stage when it transiently enters the nuclei (Ratnam et al., 2002) but later publications demonstrated the presence and nuclear localization of Dnmt1s of maternal origin and then after 2-cell stage of embryonic origin (Cirio et al., 2008; Kurihara et al., 2008). The continuous presence of Dnmt1s in the nuclei of preimplantation embryos argues against the simple mechanistic model of passive demethylation, which is 
thought to be achieved by DNA replication without maintenance of methylation due to the retention of Dnmt1o in the cytoplasm (Grohmann et al., 2005). Therefore the protection of specific sequences against active demethylation and targeting of the active and/or passive demethylation seems to be more likely.

\section{The suggested mechanisms of DNA demethylation and potential demethylases}

The mechanism behind the active paternal DNA demethylation is still unknown. Most likely the oocyte cytoplasm provides the demethylation factors, which are then directed or restricted to the paternal genome. In fact, DNA demethylation is not only limited to mammalian zygotes and PGCs; it is also observed in other cell types and under defined conditions, though it then affects only specific genomic regions and is not regarded as global (Kim et al., 2009; Klug et al., 2010; Metivier et al., 2008). In all cases, active demethylation could be either accomplished by the removal of the methyl group in C5 position of the cytidine ring directly (bona fide demethylation) or by the removal of the complete cytosine base (indirect demethylation) (Morgan et al., 2005).

So far, there are no clear evidences for the existence of a bona fide demethylase, which catalyzes the direct removal of the methyl group. Several candidates have been proposed, but none could be verified as a global demethylase. MBD2 was shown to demethylate DNA directly (Bhattacharya et al., 1999), but this data could not been reproduced by the others ( $\mathrm{Ng}$ et al., 1999). In Escherichia coli the dioxygenases AlkA and AlkB are able to directly demethylate 3-methylcytosine $(3 \mathrm{mC})$ and their human homologs $\mathrm{ABH} 2$ and $\mathrm{ABH} 3$ were identified (Duncan et al., 2002). Due to more stable $\mathrm{C}-\mathrm{C}$ bond in $5 \mathrm{mC}$ compared to the less stable $\mathrm{C}-\mathrm{N}$ bond in $3 \mathrm{mC}$, it is biochemically unlikely that a dioxygenase directly demethylates $5 \mathrm{mC}$. Nevertheless, the discovery of 5hydroxymethyl-cytidine $(5 \mathrm{hmC})$ in mammalian DNA (Kriaucionis and Heintz, 2009; Tahiliani et al., 2009) and corresponding dioxygenases TET1, TET2 and TET3 catalyzing the synthesis of $5 \mathrm{hmC}$ suggests a possible candidate mechanism for bona fide demethylation. Liutkeviciute et al. have shown that DNA methyltransferase DNMT1 is able to directly remove the hydroxymethyl group in vitro in absence of SAM (Liutkeviciute et al., 2009), implying $5 \mathrm{hmC}$ as an intermediate compound in the direct DNA demethylation. $5 \mathrm{hmC}$ could also be the target for further enzymatic oxidation, which would lead to enzymatic decarboxylation and yielding the unmodified cytosine. The recent study by lto et al. has demonstrated the presence of TET1 in mouse zygotes and thus providing the potential evidences of $5 \mathrm{hmC}$ presence in preimplantation embryos (Ito et al., 2010).

The candidate pathways for indirect demethylation all include the removal of the whole nucleotide and subsequent repair of the resulting abasic site. There is growing evidence that DNA repair processes are involved in epigenetic reprogramming events in mammalian zygotes. The fertilized oocyte has the ability to perform different types of DNA repair, including non-homologous end joining (NHEJ) and homologous recombination (HR) (Derijck et al., 2008). We and other research groups have shown that in late $\mathrm{G} 1$ mouse zygotes, during phase of active DNA demethylation, DNA strand breaks can be detected in the paternal pronucleus (Derijck et al., 2006; Hajkova et al., 2010; Wossidlo et al., 2010). These strand breaks co-localize with PARP-1, a prominent factor of the base excision repair (BER) machinery. Also during S-phase we still find more pronounced DNA strand breaks in the paternal genome (Wossidlo et al., 2010). Mouse zygotes will still initiate Sphase because of the missing G1/S-damage checkpoint (Shimura et al., 2002) and therefore the repair of such demethylation events could be performed also during S-phase. The active DNA demethylation in PGCs is also shown to be mechanistically linked to the appearance of single-stranded DNA breaks and the activation of the base excision repair (BER) pathway (Hajkova et al., 2010). Taken together these findings strongly suggest the involvement of DNA repair in the zygotic demethylation in mammals.

The indirect demethylation by direct removal of the $5 \mathrm{mC}$ nucleotide could be accomplished by DNA glycosylases. As it is shown for flowering plants, $5 \mathrm{mC}$ is actively demethylated by DNA glycosylases DEMETER (DME) and REPRESSOR OF SILENCING 1 (ROS1) (Agius et al., 2006; Grossniklaus et al., 1998; Kiyosue et al., 1999). DME mediates the DNA demethylation, which is necessary for establishing the genomic imprints in the endosperm, while ROS1 is involved in trimming DNA methylation patterns in transposons and genic regions (reviewed in (Kinoshita et al., 2008; Saze et al., 2008; Zhang et al., 2010a)). Both enzymes are bi-functional DNA glycosylases, which are able to excise $5 \mathrm{mC}$ and directly process the abasic site by intrinsic lyase activity. The resulting DNA gap is repaired by factors of BER machinery and an unmodified cytosine is then incorporated. In mammals so far no homologues for DME and ROS1 could be identified. The human and chicken DNA glycosylase MBD4 and also the thymine DNA glycosylase TDG were shown to demethylate $5 \mathrm{mC}$ in vitro (Zhu et al., 2000a; Zhu et al., 2000b). A very elegant publication by Kim et al. has shown that MBD4 plays an important role in hormone-induced transcriptionally regulated active demethylation of the cytochrome p450 27B1 gene (Kim et al., 2009). However both MBD4 and TDG showed only weak catalytic activity on the demethylation of $5 \mathrm{mC}: \mathrm{G}$ dinucleotides (Hardeland et al., 2003) and oocytes derived from MBD4-knockout-mice are still able to demethylate the paternal genome (Santos and Dean, 2004).

Another mechanism for indirect demethylation involves the enzymatic deamination of $5 \mathrm{mC}$ to thymine, followed by $\mathrm{T}: \mathrm{G}$ mismatch repair that replaces thymine with cytidine resulting in demethylation of $5 \mathrm{mC}$. Two classes of enzymes have been proposed for this mechanism: DNA deaminases and DNA methyltransferases. The DNA deaminases AID (Activation-induced deaminase) or the Apobec's have been shown to deaminate $5 \mathrm{mC}$ (Morgan et al., 2004) and a very recent publication by Popp et al. verifies the involvement of AID in genome wide demethylation of PGCs (Popp et al., 2010). In this study PGCs isolated from $\mathrm{AID}^{-/-}$embryos revealed higher DNA methylation levels compared to wild type embryos, but the demethylation activity was still prominent and offspring of AID ${ }^{-/}$parents did not show phenotypic defects indicating that AID might be not the only player in demethylation. In concert with these findings the work on interspecies heterokaryons, derived by fusion of mouse embryonic stem cells with human fibroblasts, showed that AID is required for the epigenetic reprogramming to gain pluripotency (Bhutani et al., 2010). Short interfering RNA mediated knockdown of AID in these heterokaryons abolished promoter demethylation and induction of OCT4 and NANOG gene expression. The promi- 
nent role of AID for active demethylation is further affirmed by the findings in zebrafish (Rai et al., 2008). Overexpression of AID and MBD4 in zebrafish embryos led to increased global demethylation of injected methylated DNA fragments and the zebrafish genome. If AID plays the same important role in mammalian zygotes remains to be clarified. The authors were also able to confirm the demethylating activity of another potential demethylating factor with unknown enzymatic activity, Gadd45a, which was controversially described as being involved in demethylation (Barreto et al., 2007; Li et al., 2010) but this statement was disapproved by other publications (Engel et al., 2009; Jin et al., 2008).

The DNA methyltransferases DNMT3A and DNMT3B are also proposed as indirect demethylation candidates. Metivier et al. have shown that in absence of SAM both DNMT3A and DNMT3B are able to deaminate $5 \mathrm{mC}$ to $\mathrm{T}$ (Metivier et al., 2008) in similar fashion as it was reported for prokaryotic methyltransferase M.Hpall (Shen et al., 1992). Furthermore DNMT3A associates with TDG and BER factors showing the functional link between $5 \mathrm{mC}$ deamination and coupled DNA repair. However, it is not clear whether SAM levels are reduced or restricted in the paternal pronucleus. In this aspect, the involvement of the demethylation factor Elp3 in influencing local SAM levels through its radical SAM domain activity could be of particular interest.

The indirect active demethylation could also involve the modification of $5 \mathrm{mC}$ coupled with repair of the modified $5 \mathrm{mC}$. The presence of $5 \mathrm{hmC}$ in mammalian DNA fuels such an idea and a hydroxymethyl specific zygotic DNA glycosylase could initiate subsequent BER. It was shown that several DNA glycosylases like NEIL enzymes or SMUG1 possess the enzymatic activity to recognize and cleave $5 \mathrm{hmC}$. $5 \mathrm{hmC}$ could also trigger passive DNA demethylation because the hydroxylation hinders DNMT1 to maintain DNA methylation in the newly replicated DNA strand (Tahiliani et al., 2009; Valinluck and Sowers, 2007). The list of potential DNA demethylases is summarized in Table 1.

\section{Influence of the environment on zygotic DNA demethylation}

The extensive use of different artificial reproduction technologies (ART) in cattle breeding and human reproduction raised the question how ART affect reprogramming in mammalian zygotes and consequently during preimplantation development. Alter-

TABLE 1

\section{SUGGESTED DNA DEMETHYLASES}

\begin{tabular}{|c|c|c|c|}
\hline & Enzyme & $\begin{array}{l}\text { Suggested demethylation } \\
\text { mechanism }\end{array}$ & References \\
\hline MBD2 & $\begin{array}{l}\text { methyl-binding domain } \\
\text { protein } 2\end{array}$ & bona fide demethylation & $\begin{array}{l}\text { (Bhattacharya et al., } \\
\text { 1999) }\end{array}$ \\
\hline MBD4 & $\begin{array}{l}\text { methyl-binding domain } \\
\text { protein } 4\end{array}$ & $\begin{array}{l}5 \mathrm{mC} \text { specific DNA } \\
\text { glycosylase }\end{array}$ & $\begin{array}{l}\text { (Kim et al., 2009, } \\
\text { Zhu et al., 2000a) }\end{array}$ \\
\hline GADD45a & $\begin{array}{l}\text { growth arrest and DNA- } \\
\text { damage }\end{array}$ & $\begin{array}{l}\text { nucleotide excision repair } \\
\text { mediated process inducible } \\
\text { protein } 45 \text { alpha }\end{array}$ & $\begin{array}{l}\text { (Barreto et al., 2007, } \\
\text { Li et al., 2010) }\end{array}$ \\
\hline AID & $\begin{array}{l}\text { activation-induced } \\
\text { cytidine deaminase }\end{array}$ & $5 \mathrm{mC}$ specific deaminase & $\begin{array}{l}\text { (Morgan et al., 2004, } \\
\text { Popp et al., 2010) }\end{array}$ \\
\hline DNMT3a/b & $\begin{array}{l}\text { DNA methyltransferases } \\
3 \mathrm{a} / 3 \mathrm{~b}\end{array}$ & oxidative deamination of $5 \mathrm{mC}$ & (Metivier et al., 2008) \\
\hline $\begin{array}{l}\text { DEMETER } \\
\text { ROS1 } \\
\text { DML2, DML3 }\end{array}$ & plant demethylases & $\begin{array}{l}5 \mathrm{mC} \text { specific DNA } \\
\text { glycosylases }\end{array}$ & $\begin{array}{l}\text { (Gehring et al., 2006, } \\
\text { Gehring et al., 2009) }\end{array}$ \\
\hline
\end{tabular}

ations in the DNA methylation states of preimplantation embryos have been reported in various mammalian species as a consequence of manipulations such as ICSI, SCNT, cryopreservation of embryos and gametes or even only due to in vitro culture conditions and superovulation (Santos et al., 2003; Shi et al., 2004; Shi and Haaf, 2002). Effects were documented on the whole genome scale using antibody stainings on developing embryos or by analysing DNA methylation at specific genomic regions such as imprinted loci and representative repetitive elements. The effects documented are sometimes variable, e.g. the responsiveness to environmental stress appears to vary between mammalian species. While in vitro culture conditions and ICSI manipulations lead to incomplete demethylation in rat embryos (Yoshizawa et al., 2010; Zaitseva et al., 2007) similar conditions and manipulations do not affect global demethylation in mouse embryos (Fulka and Fulka, 2006; Peters et al., 2009). The maintenance of genomic imprints appeared to be more sensitive indicators in different mammals. Hypomethylation of paternal $\mathrm{H} 19$ allele was reported for individual mouse (Fauque et al., 2007) and for human (Zechner et al., 2009) embryos conceived by in vitro fertilization. In general, the fidelity of human ART is actively debated and the reports claiming ART being save for the imprints (Tierling et al., 2009) are published along with those raising the concerns about the issue (Katari et al., 2009). Therefore the impact of zygotic demethylation on imprinting requires additional investigations. With human artificial reproduction becoming now a common medical practice, further progress in cultivation and manipulation technologies is still needed.

\section{Conclusions}

The successful development of a newly formed mammalian embryo includes various epigenetic reprogramming events. These events equalize the extremely epigenetically different chromosomes of sperm and oocyte and make them competent for further development. Both DNA and histone modifications in parental pronuclei of the mammalian zygote should synergistically form a specific epigenetic landscape in order to achieve a certain degree of genomic plasticity. Such plasticity is the prerequisite for establishing the totipotency state first, which then transforms into pluripotency in ICM cells at blastocyst stage. It is the mammalian ooplasm which provides the machinery for this reprogramming, because not only incoming sperm genome, but also somatic cell donor nuclei in SCNT embryos are epigenetically altered. The DNA methylation reprogramming activity is part of this process. The mechanism of the DNA demethylation is still not solved, but more and more data show the involvement of DNA repair events. Beyond that, the biological reasons for the changes in zygotic DNA methylation and histone modifications are heavily debated. One obvious interpretation is the necessity of DNA methylation reprogramming for subsequent EGA. Indeed, in mouse and rat embryos EGA begins already at the end of the first cell cycle, but bovine and rabbit embryos activate their genomes few cycles later - at 8-16 cell stage (Kanka, 2003). However, data on sperm methylation profile show hypomethylation of promoter regions, which means the paternal genes are already in the stand by mode to initiate the transcription (Farthing et al., 2008). On the other hand the genome wide epigenetic changes could probably serve as a "genomes compatibility proof" - a mechanism allowing the 
transcription through the entire paternal genome (not only genic regions) in order to reveal its potential in supporting the development of the embryo. Furthermore it might also be compared with tabula rasa conception when the oocyte erases sperm inherited epigenetic information and then re-establishes it accordingly to the developmental program stored in the ooplasm. As recent data show, the latter could only be partially true, since some of sperm epigenetic heritage remains after zygotic reprogramming and plays not the least role in further development (Brykczynska etal., 2010; Hammoud et al., 2009). More detailed studies of different epigenetic reprogramming events in preimplantation mammalian embryos are hindered by the availability of the material. We hope that so far unresolved issues can be clarified with the development of new high throughput sequencing technologies requiring less material and providing not only conventional sequence information but also allowing discrimination of different base modifications, such as methylation and hydroxymethylation (Clarke et al., 2009; Flusberg et al., 2010).

\section{References}

ADENOT, P.G., MERCIER, Y., RENARD, J.P. and THOMPSON, E.M. (1997) Differential $\mathrm{H} 4$ acetylation of paternal and maternal chromatin precedes DNA replication and differential transcriptional activity in pronuclei of 1-cell mouse embryos. Development 124: 4615-4625.

AGIUS, F., KAPOOR, A. and ZHU, J.K. (2006). Role of the Arabidopsis DNA glycosylase/lyase ROS1 in active DNA demethylation. Proc Nat/ Acad Sci USA 103: 11796-11801.

ARANYI, T. and PALDI, A. (2006). The constant variation: DNA methylation changes during preimplantation development. FEBS letters 580: 6521-6526.

ARNEY, K.L., BAO, S., BANNISTER, A.J., KOUZARIDES, T. and SURANI, M.A. (2002). Histone methylation defines epigenetic asymmetry in the mouse zygote. Int J Dev Bio/46: 317-320.

BARRETO, G., SCHAFER, A., MARHOLD, J., STACH, D., SWAMINATHAN, S.K., HANDA, V., DODERLEIN, G., MALTRY, N., WU, W., LYKO, F. et al. (2007). Gadd45a promotes epigenetic gene activation by repair-mediated DNA demethylation. Nature 445: 671-675.

BERGER, S.L., KOUZARIDES, T., SHIEKHATTAR, R. and SHILATIFARD, A. (2009). An operational definition of epigenetics. Genes Dev 23: 781-783.

BHATTACHARYA, S.K., RAMCHANDANI, S., CERVONI, N. and SZYF, M. (1999). A mammalian protein with specific demethylase activity for $\mathrm{mCpG}$ DNA. Nature 397: 579-583.

BHUTANI, N., BRADY, J.J., DAMIAN, M., SACCO, A., CORBEL, S.Y. and BLAU, H.M. (2010). Reprogramming towards pluripotency requires AID-dependent DNA demethylation. Nature 463: 1042-1047.

BIRD, A.P. and WOLFFE, A.P. (1999). Methylation-induced repression-belts, braces, and chromatin. Cel/99: 451-454.

BRYKCZYNSKA, U., HISANO, M., ERKEK, S., RAMOS, L., OAKELEY, E.J., ROLOFF, T.C., BEISEL, C., SCHUBELER, D., STADLER, M.B. and PETERS, A.H.F.M. (2010). Repressive and active histone methylation mark distinct promoters in human and mouse spermatozoa. Nature structural \& molecular biology 17: 679-687.

CERVONI, N. and SZYF, M. (2001). Demethylase activity is directed by histone acetylation. J Biol Chem 276: 40778-40787.

CHANG, K.H., LIM, J.M., KANG, S.K., LEE, B.C., MOON, S.Y. and HWANG, W.S. (2003). Blastocyst formation, karyotype, and mitochondrial DNA of interspecies embryos derived from nuclear transfer of human cord fibroblasts into enucleated bovine oocytes. Fertil Steril 80: 1380-1387.

CIRIO, M.C., RATNAM, S., DING, F., REINHART, B., NAVARA, C. and CHAILLET, J.R. (2008). Preimplantation expression of the somatic form of Dnmt1 suggests a role in the inheritance of genomic imprints. BMC Dev Bio/8: 9.

CLARKE, J., WU, H.C., JAYASINGHE, L., PATEL, A., REID, S. and BAYLEY, H. (2009). Continuous base identification for single-molecule nanopore DNA sequencing. Nat Nanotechno/4: 265-270.

DEAN, W., SANTOS, F., STOJKOVIC, M., ZAKHARTCHENKO, V., WALTER, J., WOLF, E. and REIK, W. (2001). Conservation of methylation reprogramming in mammalian development: aberrant reprogramming in cloned embryos. Proc Natl Acad Sci USA 98: 13734-13738.

DERIJCK, A., VAN DER HEIJDEN, G., GIELE, M., PHILIPPENS, M. and DE BOER, P. (2008). DNA double strand break repair in parental chromatin of mouse zygotes, the first cell cycle as an origin of de novo mutation. Human molecular genetics 17: 1922-1937.

DERIJCK, A.A., VAN DER HEIJDEN, G.W., GIELE, M., PHILIPPENS, M.E., VAN BAVEL, C.C. and DE BOER, P. (2006). gammaH2AX signalling during sperm chromatin remodelling in the mouse zygote. DNA repair5: 959-971.

DUNCAN, T., TREWICK, S.C., KOIVISTO, P., BATES, P.A., LINDAHL, T. and SEDGWICK, B. (2002). Reversal of DNA alkylation damage by two human dioxygenases. Proc Nat/ Acad Sci USA 99: 16660-16665.

ENGEL, N., TRONT, J.S., ERINLE, T., NGUYEN, N., LATHAM, K.E., SAPIENZA, C., HOFFMAN, B. and LIEBERMANN, D.A. (2009). Conserved DNA methylation in Gadd45a(-/-) mice. Epigenetics 4: 98-99.

EPSZTEJN-LITMAN, S., FELDMAN, N., ABU-REMAILEH, M., SHUFARO, Y., GERSON, A., UEDA, J., DEPLUS, R., FUKS, F., SHINKAI, Y., CEDAR, H. et al. (2008). De novo DNA methylation promoted by G9a prevents reprogramming of embryonically silenced genes. Nat Struct Mol Biol 15: 1176-1183.

ERHARDT, S., SU, I.H., SCHNEIDER, R., BARTON, S., BANNISTER, A.J., PEREZ-BURGOS, L., JENUWEIN, T., KOUZARIDES, T., TARAKHOVSKY, A. and SURANI, M.A. (2003). Consequences of the depletion of zygotic and embryonic enhancer of zeste 2 during preimplantation mouse development. Development 130: 4235-4248

EVANS, M.J. and KAUFMAN, M.H. (1981). Establishment in culture of pluripotential cells from mouse embryos. Nature 292: 154-156.

FARTHING, C.R., FICZ, G., NG, R.K., CHAN, C.-F., ANDREWS, S., DEAN, W., HEMBERGER, M. and REIK, W. (2008). Global Mapping of DNA Methylation in Mouse Promoters Reveals Epigenetic Reprogramming of Pluripotency Genes. PLOS Genetics 4: e1000116.

FAUQUE, P., JOUANNET, P., LESAFFRE, C., RIPOCHE, M.A., DANDOLO, L. VAIMAN, D. and JAMMES, H. (2007). Assisted Reproductive Technology affects developmental kinetics, $\mathrm{H} 19$ Imprinting Control Region methylation and H19 gene expression in individual mouse embryos. BMC Dev Bio/7: 116.

FLUSBERG, B.A., WEBSTER, D.R., LEE, J.H., TRAVERS, K.J., OLIVARES, E.C. CLARK, T.A., KORLACH, J. and TURNER, S.W. (2010). Direct detection of DNA methylation during single-molecule, real-time sequencing. Nat Meth 7 : 461-465.

FUKS, F., HURD, P.J., WOLF, D., NAN, X., BIRD, A.P. and KOUZARIDES, T. (2003). The methyl-CpG-binding protein MeCP2 links DNA methylation to histone methylation. J Biol Chem 278: 4035-4040.

FULKA, H. and FULKA, J., JR. (2006). No differences in the DNA methylation pattern in mouse zygotes produced in vivo, in vitro, or by intracytoplasmic sperm injection. Fertil Steril 86: 1534-1536.

FULKA, H., MRAZEK, M., TEPLA, O. and FULKA, J., JR. (2004). DNA methylation pattern in human zygotes and developing embryos. Reproduction (Cambridge, England) 128: 703-708.

FULKA, J., FULKA, H., SLAVIK, T., OKADA, K. and FULKA, J., JR. (2006). DNA methylation pattern in pig in vivo produced embryos. Histochem. Cell Biol. 126: 213-217.

GEHRING, M., HUH, J.H., HSIEH, T.F., PENTERMAN, J., CHOI, Y., HARADA, J.J . GOLDBERG, R.B. and FISCHER, R.L. (2006). DEMETER DNA glycosylase establishes MEDEA polycomb gene self-imprinting by allele-specific demethylation. Cel/124: 495-506.

GEHRING, M., REIK, W. and HENIKOFF, S. (2009). DNA demethylation by DNA repair. Trends Genet 25: 82-90.

GROHMANN, M., SPADA, F., SCHERMELLEH, L., ALENINA, N., BADER, M., CARDOSO, M.C. and LEONHARDT, H. (2005). Restricted mobility of Dnmt1 in preimplantation embryos: implications for epigenetic reprogramming. $B M C$ Dev. Biol. 5: 18

GROSSNIKLAUS, U., VIELLE-CALZADA, J.P., HOEPPNER, M.A. and GAGLIANO, W.B. (1998). Maternal control of embryogenesis by MEDEA, a polycomb group gene in Arabidopsis. Science 280: 446-450. 
HAJKOVA, P., ANCELIN, K., WALDMANN, T., LACOSTE, N., LANGE, U.C., CESARI, F., LEE, C., ALMOUZNI, G., SCHNEIDER, R. and SURANI, M.A. (2008). Chromatin dynamics during epigenetic reprogramming in the mouse germ line. Nature 452: 877-881.

HAJKOVA, P., ERHARDT, S., LANE, N., HAAF, T., EL-MAARRI, O., REIK, W., WALTER, J. and SURANI, M.A. (2002). Epigenetic reprogramming in mouse primordial germ cells. Mech. Dev. 117: 15-23.

HAJKOVA, P., JEFFRIES, S.J., LEE, C., MILLER, N., JACKSON, S.P. and SURANI, M.A. (2010). Genome-wide reprogramming in the mouse germ line entails the base excision repair pathway. Science 329: 78-82.

HAMMER, C.J., TYLER, H.D., LOSKUTOFF, N.M., ARMSTRONG, D.L., FUNK, D.J., LINDSEY, B.R. and SIMMONS, L.G. (2001). Compromised development of calves (Bos gaurus) derived from in vitro-generated embryos and transferred interspecifically into domestic cattle (Bos taurus). Theriogenology 55: 14471455.

HAMMOUD, S.S., NIX, D.A., ZHANG, H., PURWAR, J., CARRELL, D.T. and CAIRNS, B.R. (2009). Distinctive chromatin in human sperm packages genes for embryo development. Nature 460: 473-478.

HARDELAND, U., BENTELE, M., JIRICNY, J. and SCHAR, P. (2003). The versatile thymine DNA-glycosylase: a comparative characterization of the human, Drosophila and fission yeast orthologs. Nuc. Acid. Res. 31: 2261-2271.

HASHIMSHONY, T., ZHANG, J., KESHET, I., BUSTIN, M. and CEDAR, H. (2003). The role of DNA methylation in setting up chromatin structure during development. Nat Genet 34: 187-192.

HIRASAWA, R., CHIBA, H., KANEDA, M., TAJIMA, S., LI, E., JAENISCH, R. and SASAKI, H. (2008). Maternal and zygotic Dnmt1 are necessary and sufficient for the maintenance of DNA methylation imprints during preimplantation development. Genes Dev. 22: 1607-1616.

HO, L. and CRABTREE, G.R. (2010). Chromatin remodelling during development. Nature 463: 474-484

HOU, J., LIU, L., ZHANG, J., CUI, X.H., YAN, F.X., GUAN, H., CHEN, Y.F. and AN, X.R. (2008). Epigenetic modification of histone 3 at lysine 9 in sheep zygotes and its relationship with DNA methylation. BMC Dev. Biol. 8: 60.

ITO, S., D'ALESSIO, A.C., TARANOVA, O.V., HONG, K., SOWERS, L.C. and ZHANG, Y. (2010). Role of Tet proteins in $5 \mathrm{mC}$ to $5 \mathrm{hmC}$ conversion, ES-cell self-renewal and inner cell mass specification. Nature 466: 1129-1133.

JENUWEIN, T. and ALLIS, C.D. (2001). Translating the histone code. Science293: 1074-1080.

JIN, S.-G., KADAM, S. and PFEIFER, G.P. (2010). Examination of the specificity of DNA methylation profiling techniques towards 5-methylcytosine and 5hydroxymethylcytosine. Nucl. Acids Res.gkq223.

JIN, S.G., GUO, C. and PFEIFER, G.P. (2008). GADD45A does not promote DNA demethylation. PLOS genetics 4: e1000013.

KAFRI, T., GAO, X. and RAZIN, A. (1993). Mechanistic aspects of genome-wide demethylation in the preimplantation mouse embryo. Proc Natl Acad Sci USA 90: 10558-10562.

KANKA, J. (2003). Gene expression and chromatin structure in the pre-implantation embryo. Theriogenology 59: 3-19.

KATARI, S., TURAN, N., BIBIKOVA, M., ERINLE, O., CHALIAN, R., FOSTER, M., GAUGHAN, J.P., COUTIFARIS, C. and SAPIENZA, C. (2009). DNA methylation and gene expression differences in children conceived in vitro or in vivo. Hum Mol Genet 18: 3769-3778.

KIM, J.M., LIU, H., TAZAKI, M., NAGATA, M. and AOKI, F. (2003). Changes in histone acetylation during mouse oocyte meiosis. J Cell Bio/162: 37-46.

KIM, M.S., KONDO, T., TAKADA, I., YOUN, M.Y., YAMAMOTO, Y., TAKAHASHI, S., MATSUMOTO, T., FUJIYAMA, S., SHIRODE, Y., YAMAOKA, I. et al. (2009). DNA demethylation in hormone-induced transcriptional derepression. Nature 461: 1007-1012.

KIM, S.H., KANG, Y.K., KOO, D.B., KANG, M.J., MOON, S.J., LEE, K.K. and HAN, Y.M. (2004). Differential DNA methylation reprogramming of various repetitive sequences in mouse preimplantation embryos. Biochem Biophys Res Commun 324: $58-63$

KINOSHITA, T., IKEDA, Y. and ISHIKAWA, R. (2008). Genomic imprinting: a balance between antagonistic roles of parental chromosomes. Semin Cel/ Dev Biol 19: 574-579

KIYOSUE, T., OHAD, N., YADEGARI, R., HANNON, M., DINNENY, J., WELLS, D.,
KATZ, A., MARGOSSIAN, L., HARADA, J.J., GOLDBERG, R.B. et al. (1999). Control of fertilization-independent endosperm development by the MEDEA polycomb gene in Arabidopsis. Proc Natl Acad Sci USA 96: 4186-4191.

KLUG, M., HEINZ, S., GEBHARD, C., SCHWARZFISCHER, L., KRAUSE, S.W. ANDREESEN, R. and REHLI, M. (2010). Active DNA demethylation in human postmitotic cells correlates with activating histone modifications, but not transcription levels. Genome Bio/11: R63.

KOMASHKO, V.M. and FARNHAM, P.J. (2010). 5-azacytidine treatment reorganizes genomic histone modification patterns. Epigenetics 5: 229-240.

KOUZARIDES, T. (2007). Chromatin modifications and their function. Ce// 128 693-705.

KRIAUCIONIS, S. and HEINTZ, N. (2009). The nuclear DNA base 5hydroxymethylcytosine is present in Purkinje neurons and the brain. Science 324: 929-930.

KURIHARA, Y., KAWAMURA, Y., UCHIJIMA, Y., AMAMO, T., KOBAYASHI, H., ASANO, T. and KURIHARA, H. (2008). Maintenance of genomic methylation patterns during preimplantation development requires the somatic form of DNA methyltransferase 1. Dev. Biol. 313: 335-346.

LANE, N., DEAN, W., ERHARDT, S., HAJKOVA, P., SURANI, A., WALTER, J. and REIK, W. (2003). Resistance of IAPs to methylation reprogramming may provide a mechanism for epigenetic inheritance in the mouse. Genesis 35: 8893.

LEE, J., INOUE, K., ONO, R., OGONUKI, N., KOHDA, T., KANEKO-ISHINO, T., OGURA, A. and ISHINO, F. (2002). Erasing genomic imprinting memory in mouse clone embryos produced from day 11.5 primordial germ cells. Develop ment 129: 1807-1817.

LEHNERTZ, B., UEDA, Y., DERIJCK, A.A., BRAUNSCHWEIG, U., PEREZBURGOS, L., KUBICEK, S., CHEN, T., LI, E., JENUWEIN, T. and PETERS, A.H. (2003). Suv39h-mediated histone H3 lysine 9 methylation directs DNA methylation to major satellite repeats at pericentric heterochromatin. Curr Biol 13: 1192-1200.

LEPIKHOV, K. and WALTER, J. (2004). Differential dynamics of histone H3 methylation at positions K4 and K9 in the mouse zygote. BMC Dev Bio/4: 12.

LEPIKHOV, K., ZAKHARTCHENKO, V., HAO, R., YANG, F., WRENZYCKI, C., NIEMANN, H., WOLF, E. and WALTER, J. (2008). Evidence for conserved DNA and histone $\mathrm{H} 3$ methylation reprogramming in mouse, bovine and rabbit zygotes. Epigenetics \& chromatin 1: 8.

LI, Y., ZHAO, M., YIN, H., GAO, F., WU, X., LUO, Y., ZHAO, S., ZHANG, X., SU, Y., HU, N. et al. (2010). Gadd45a overexpression contributes to autoimmunity by promoting DNA demethylation in lupus T cells. Arthritis Rheum 62: 14381447.

LIU, H., KIM, J.M. and AOKI, F. (2004a). Regulation of histone H3 lysine 9 methylation in oocytes and early pre-implantation embryos. Development 131 : 2269-2280.

LIU, S.Z., ZHOU, Z.M., CHEN, T., ZHANG, Y.L., WEN, D.C., KOU, Z.H., LI, Z.D., SUN, Q.Y. and CHEN, D.Y. (2004b). Blastocysts produced by nuclear transfer between chicken blastodermal cells and rabbit oocytes. Mol Reprod Dev 69: 296-302.

LIUTKEVICIUTE, Z., LUKINAVICIUS, G., MASEVICIUS, V., DAUJOTYTE, D. and KLIMASAUSKAS, S. (2009). Cytosine-5-methyltransferases add aldehydes to DNA. Nat Chem Biol 5: 400-402.

MAYER, W., NIVELEAU, A., WALTER, J., FUNDELE, R. and HAAF, T. (2000). Demethylation of the zygotic paternal genome. Nature 403: 501-502.

MCGRATH, J. and SOLTER, D. (1983). Nuclear transplantation in mouse embryos. $J$ Exp ZOo/228: 355-362.

MCGRATH, J. and SOLTER, D. (1984). Completion of mouse embryogenesis requires both the maternal and paternal genomes. Cel/37: 179-183.

MCGRATH, J. and SOLTER, D. (1986). Nuclear and cytoplasmic transfer in mammalian embryos. Dev Bio/4: 37-55.

MEO, S.C., LEAL, C.L. and GARCIA, J.M. (2004). Activation and early parthenogenesis of bovine oocytes treated with ethanol and strontium. Anim Reprod Sci 81: $35-46$.

METIVIER, R., GALLAIS, R., TIFFOCHE, C., LE PERON, C., JURKOWSKA, R.Z., CARMOUCHE, R.P., IBBERSON, D., BARATH, P., DEMAY, F., REID, G. et al. (2008). Cyclical DNA methylation of a transcriptionally active promoter. Nature 452: $45-50$. 
MONK, M., BOUBELIK, M. and LEHNERT, S. (1987). Temporal and regional changes in DNA methylation in the embryonic, extraembryonic and germ cell lineages during mouse embryo development. Development 99: 371-382.

MORGAN, H.D., DEAN, W., COKER, H.A., REIK, W. and PETERSEN-MAHRT, S.K. (2004). Activation-induced cytidine deaminase deaminates 5-methylcytosine in DNA and is expressed in pluripotent tissues: implications for epigenetic reprogramming. J Biol Chem 279: 52353-52360.

MORGAN, H.D., SANTOS, F., GREEN, K., DEAN, W. and REIK, W. (2005). Epigenetic reprogramming in mammals. Human Molec. Genet. $14 \mathrm{Spec}$ No 1: R47-58.

NAGAI, T. (1987). Parthenogenetic activation of cattle follicular oocytes in vitrowith ethanol. Gamete Res 16: 243-249.

NAKAMURA, T., ARAI, Y., UMEHARA, H., MASUHARA, M., KIMURA, T., TANIGUCHI, H., SEKIMOTO, T., IKAWA, M., YONEDA, Y., OKABE, M. et al. (2007). PGC7/Stella protects against DNA demethylation in early embryogenesis. Nature Cell Biol. 9: 64-71.

NG, H.H., ZHANG, Y., HENDRICH, B., JOHNSON, C.A., TURNER, B.M., ERDJUMENT-BROMAGE, H., TEMPST, P., REINBERG, D. and BIRD, A. (1999). MBD2 is a transcriptional repressor belonging to the MeCP1 histone deacetylase complex. Nature Genet. 23: 58-61.

OKADA, Y., YAMAGATA, K., HONG, K., WAKAYAMA, T. and ZHANG, Y. (2010). $A$ role for the elongator complex in zygotic paternal genome demethylation. Nature 463: 554-558.

OSWALD, J., ENGEMANN, S., LANE, N., MAYER, W., OLEK, A., FUNDELE, R., DEAN, W., REIK, W. and WALTER, J. (2000). Active demethylation of the paternal genome in the mouse zygote. Curr Bio/10: 475-478.

PETERS, D.D., LEPIKHOV, K., RODENACKER, K., MARSCHALL, S., BOERSMA, A., HUTZLER, P., SCHERB, H., WALTER, J. and DE ANGELIS, M.H. (2009). Effect of IVF and laser zona dissection on DNA methylation pattern of mouse zygotes. Mamm Genome 20: 664-673.

POPP, C., DEAN, W., FENG, S., COKUS, S.J., ANDREWS, S., PELLEGRINI, M., JACOBSEN, S.E. and REIK, W. (2010). Genome-wide erasure of DNA methylation in mouse primordial germ cells is affected by AID deficiency. Nature 463: 1101-1105

PRATHER, R.S., EICHEN, P.A., NICKS, D.K. and PETERS, M.S. (1991). Artificial activation of porcine oocytes matured in vitro. Mol Reprod Dev 28: 405-409.

RAI, K., HUGGINS, I.J., JAMES, S.R., KARPF, A.R., JONES, D.A. and CAIRNS, B.R. (2008). DNA demethylation in zebrafish involves the coupling of a deaminase, a glycosylase, and gadd45. Cel/135: 1201-1212.

RATNAM, S., MERTINEIT, C., DING, F., HOWELL, C.Y., CLARKE, H.J., BESTOR, T.H., CHAILLET, J.R. and TRASLER, J.M. (2002). Dynamics of Dnmt1 methyltransferase expression and intracellular localization during oogenesis and preimplantation development. Dev Bio/245: 304-314.

REESE, K.J., LIN, S., VERONA, R.I., SCHULTZ, R.M. and BARTOLOMEI, M.S. (2007). Maintenance of Paternal Methylation and Repression of the Imprinted H19 Gene Requires MBD3. PLoS Genet 3: e137.

ROUGIER, N., BOURC'HIS, D., GOMES, D.M., NIVELEAU, A., PLACHOT, M., PALDI, A. and VIEGAS-PEQUIGNOT, E. (1998). Chromosome methylation patterns during mammalian preimplantation development. Genes Dev. 12: 2108-2113.

SANTOS, F. and DEAN, W. (2004). Epigenetic reprogramming during early development in mammals. Reproduction 127: 643-651.

SANTOS, F., HENDRICH, B., REIK, W. and DEAN, W. (2002). Dynamic reprogramming of DNA methylation in the early mouse embryo. Dev Bio/241: 172-182.

SANTOS, F., PETERS, A.H., OTTE, A.P., REIK, W. and DEAN, W. (2005). Dynamic chromatin modifications characterise the first cell cycle in mouse embryos. Dev Bio/280: 225-236.

SANTOS, F., ZAKHARTCHENKO, V., STOJKOVIC, M., PETERS, A., JENUWEIN, T., WOLF, E., REIK, W. and DEAN, W. (2003). Epigenetic marking correlates with developmental potential in cloned bovine preimplantation embryos. Curr Biol13: 1116-1121.

SARMENTO, O.F., DIGILIO, L.C., WANG, Y., PERLIN, J., HERR, J.C., ALLIS, C.D. and COONROD, S.A. (2004). Dynamic alterations of specific histone modifications during early murine development. J Cel/ Sci 117: 4449-4459.

SAZE, H., SASAKI, T. and KAKUTANI, T. (2008). Negative regulation of DNA methylation in plants. Epigenetics 3: 122-124.
SEKI, Y., HAYASHI, K., ITOH, K., MIZUGAKI, M., SAITOU, M. and MATSUI, Y (2005). Extensive and orderly reprogramming of genome-wide chromatin modifications associated with specification and early development of germ cells in mice. Dev Bio/278: 440-458.

SHEN, J.C., RIDEOUT, W.M., 3RD and JONES, P.A. (1992). High frequency mutagenesis by a DNA methyltransferase. Cel/71: 1073-1080.

SHERMAN, M.I. (1975). The culture of cells derived from mouse blastocysts. Cell 5: 343-349.

SHI, W., DIRIM, F., WOLF, E., ZAKHARTCHENKO, V. and HAAF, T. (2004). Methylation Reprogramming and Chromosomal Aneuploidy in In vivoFertilized and Cloned Rabbit Preimplantation Embryos. Biol Reprod71: 340-347

SHI, W. and HAAF, T. (2002). Aberrant methylation patterns at the two-cell stage as an indicator of early developmental failure. Mol Reprod Dev63: 329-334.

SHIMURA, T., INOUE, M., TAGA, M., SHIRAISHI, K., UEMATSU, N., TAKEI, N., YUAN, Z.M., SHINOHARA, T. and NIWA, O. (2002). p53-dependent S-phase damage checkpoint and pronuclear cross talk in mouse zygotes with $X$ irradiated sperm. Mol Cel/ Bio/22: 2220-2228.

SPINACI, M., FANTINATI, P., NICOLETTI, S., CAPPANNARI, C. and MATTIOLI, M. (2003). Paternal chromatin remodelling in mouse oocytes following fertilization. Veterinary Res. Commun. 27 Suppl 1: 241-243.

TAHILIANI, M., KOH, K.P., SHEN, Y., PASTOR, W.A., BANDUKWALA, H., BRUDNO, Y., AGARWAL, S., IYER, L.M., LIU, D.R., ARAVIND, L. etal. (2009). Conversion of 5-Methylcytosine to 5-Hydroxymethylcytosine in Mammalian DNA by the MLL Fusion Partner TET1. Science.1170116.

TAMARU, H., ZHANG, X., MCMILLEN, D., SINGH, P.B., NAKAYAMA, J., GREWAL, S.I., ALLIS, C.D., CHENG, X. and SELKER, E.U. (2003). Trimethylated lysine 9 of histone $\mathrm{H} 3$ is a mark for DNA methylation in Neurospora crassa. Nat Genet 34: 75-79.

TIERLING, S., SOUREN, N.Y., GRIES, J., LO PORTO, C., GROTH, M., LUTSIK, P., NEITZEL, H., UTZ-BILLING, I., GILLESSEN-KAESBACH, G., KENTENICH, $H$. et al. (2010). Assisted reproductive technologies do not enhance the variability of DNA methylation imprints in human. JMed Genet 47: 371-376.

TORRES-PADILLA, M.E., BANNISTER, A.J., HURD, P.J., KOUZARIDES, T. and ZERNICKA-GOETZ, M. (2006). Dynamic distribution of the replacement histone variant H3.3 in the mouse oocyte and preimplantation embryos. Int. J. Dev. Biol. 50: 455-461.

VALINLUCK, V. and SOWERS, L.C. (2007). Endogenous Cytosine Damage Products Alter the Site Selectivity of Human DNA Maintenance Methyltransferase DNMT1 Cancer Res 67: 946-950 (doi: 10.1158/0008-5472.CAN-06-3123).

VAN DER HEIJDEN, G.W., DIEKER, J.W., DERIJCK, A.A., MULLER, S., BERDEN, J.H., BRAAT, D.D., VAN DER VLAG, J. and DE BOER, P. (2005). Asymmetry in Histone $\mathrm{H} 3$ variants and lysine methylation between paternal and maternal chromatin of the early mouse zygote. Mech Dev 122: 1008-1022.

VIRE, E., BRENNER, C., DEPLUS, R., BLANCHON, L., FRAGA, M., DIDELOT, C. MOREY, L., VAN EYNDE, A., BERNARD, D., VANDERWINDEN, J.M. et al. (2006). The Polycomb group protein EZH2 directly controls DNA methylation. Nature 439: 871-874.

WANG, S.C. and FREY, P.A. (2007). S-adenosylmethionine as an oxidant: the radical SAM superfamily. Trends Biochem Sci32: 101-110.

WEBER, M., DAVIES, J.J., WITTIG, D., OAKELEY, E.J., HAASE, M., LAM, W.L. and SCHUBELER, D. (2005). Chromosome-wide and promoter-specific analyses identify sites of differential DNA methylation in normal and transformed human cells. Nature Genet. 37: 853-862.

WOSSIDLO, M., ARAND, J., SEBASTIANO, V., LEPIKHOV, K., BOIANI, M., REINHARDT, R., SCHOLER, H. and WALTER, J. (2010). Dynamic link of DNA demethylation, DNA strand breaks and repair in mouse zygotes. Embo $J 29$ : 1877-1888.

YOSHIZAWA, Y., KATO, M., HIRABAYASHI, M. and HOCHI, S. (2010). Impaired active demethylation of the paternal genome in pronuclear-stage rat zygotes produced by in vitrofertilization or intracytoplasmic sperm injection. MolReprod Dev 77: 69-75.

ZAITSEVA, I., ZAITSEV, S., ALENINA, N., BADER, B. and KRIVOKHARCHENKO, A. (2007). Dynamics of DNA-demethylation in early mouse and rat embryos developed in vivo and in vitro. Molecular Reproduction and Development 74: 1255-1261.

ZECHNER, U., PLIUSHCH, G., SCHNEIDER, E., EL HAJJ, N., TRESCH, A., 
SHUFARO, Y., SEIDMANN, L., COERDT, W., MULLER, A.M. and HAAF, T. (2009). Quantitative methylation analysis of developmentally important genes in human pregnancy losses after ART and spontaneous conception. Mol Hum Reprod. gap107.

ZHANG, M., KIMATU, J.N., XU, K. and LIU, B. (2010a). DNA cytosine methylation in plant development. $J$ Genet Genomics 37: 1-12.

ZHANG, Y., JURKOWSKA, R., SOEROES, S., RAJAVELU, A., DHAYALAN, A., BOCK, I., RATHERT, P., BRANDT, O., REINHARDT, R., FISCHLE, W. et al. (2010b). Chromatin methylation activity of Dnmt3a and Dnmt3a/3L is guided by interaction of the ADD domain with the histone $\mathrm{H} 3$ tail. Nucleic Acids Res 38 :
4246-4253.

ZHU, B., ZHENG, Y., ANGLIKER, H., SCHWARZ, S., THIRY, S., SIEGMANN, M. and JOST, J.P. (2000a). 5-Methylcytosine DNA glycosylase activity is also present in the human MBD4 (G/T mismatch glycosylase) and in a related avian sequence. Nucleic Acids Res 28: 4157-4165.

ZHU, B., ZHENG, Y., HESS, D., ANGLIKER, H., SCHWARZ, S., SIEGMANN, M., THIRY, S. and JOST, J.P. (2000b). 5-methylcytosine-DNA glycosylase activity is present in a cloned $\mathrm{G} / \mathrm{T}$ mismatch DNA glycosylase associated with the chicken embryo DNA demethylation complex. ProcNat/Acad SciUSA97: 51355139 .

\section{Further Related Reading, published previously in the Int. J. Dev. Biol.}

See our recent Special Issue Developmental Hematopoiesis edited by Charles Durand, Tierry Jaffredo and Alexander Medvinsky at: http://www.ijdb.ehu.es/web/contents.php?vol=54\&issue=6-7

Distribution of p53 binding protein 1 (53BP1) and phosphorylated H2A.X during mouse preimplantation development in the absence of DNA damage

ZIEGLER-BIRLING, C., HELMRICH, A., TORA, L. and TORRES-PADILLA, M.E. (2009)

Int J Dev Biol 53: 1003-1011

Hypomethylation of paternal DNA in the late mouse zygote is not essential for development POLANSKI, Z., MOTOSUGI, N., TSURUMI, C., HIIRAGI, T. and HOFFMANN, S. (2008)

Int J Dev Biol 52: 295-298

Dynamic distribution of the replacement histone variant $\mathrm{H} 3.3$ in the mouse oocyte and preimplantation embryos TORRES-PADILLA, M.E., BANNISTER, A.J., HURD, P.J., KOUZARIDES, T. and ZERNICKA-GOETZ, M. (2006) Int J Dev Biol 50: 455-461

Histone methylation defines epigenetic asymmetry in the mouse zygote ARNEY, K.L., BAO, S., BANNISTER, A.J., KOUZARIDES, T. and SURANI, M.A. (2002) Int J Dev Biol 46: 317-320

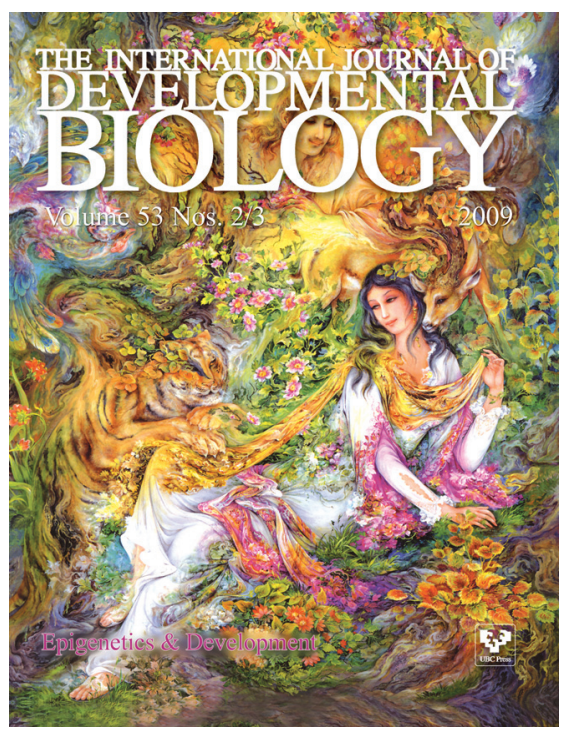

5 yr ISI Impact Factor $(2009)=3.253$

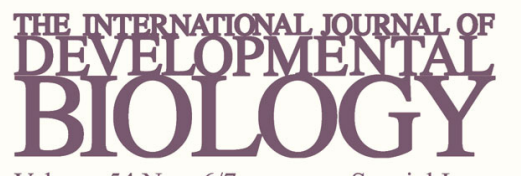

Volume 54 Nos. 6/7
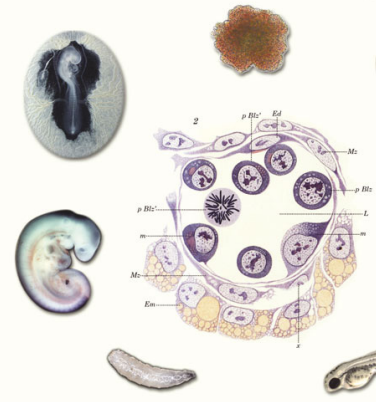

Developmental Hematopoiesis
Special Issue
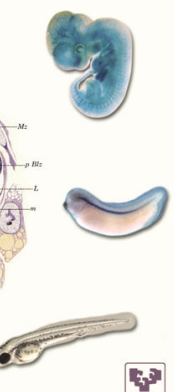

viscen

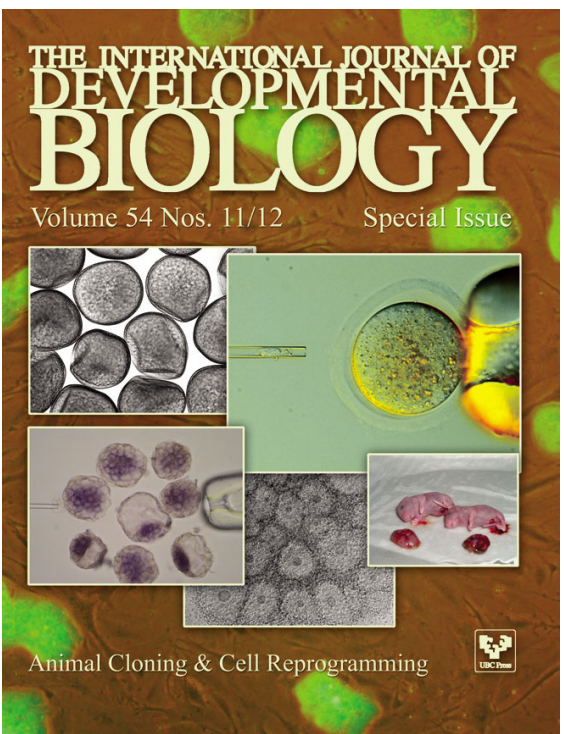

